$\xi=$ 잘

\title{
Knowledge, attitude and perception of orthodontic treatment among dental students
}

\author{
Riya Agrawal * \\ Intern Peoples Dental Academy Bhopal M.P. \\ *Corresponding author E-mail: Agrawalriya455@gmail.com
}

\begin{abstract}
Introduction: Malocclusion is known to contribute overall health status, as well as affecting individual's psychosocial health.

Aim: To establish knowledge, attitude and perception of orthodontics treatment among dental students of one of the dental college of M.P.

Material \& Method: A descriptive cross study was carried out among 300 undergraduate dental students of people dental academy Bhopal M.P. India.

Each classroom of the participants were visited. Self-administered questionnaire were distributed to a 300 students. The scores were calculated, and statistical analysis were done. Categorical variables were evaluated using a Chi-square test with the level of significance of $\mathrm{P}<0.001$.

Results: About $85 \%$ of the students were aware of their dental esthetics. About $85 \%$ of females were satisfied with the attractiveness of their teeth when compared to $70 \%$ males. House surgeons had more positive attitude compared to the 1 st year students.

Conclusion: The dental students had good knowledge about the orthodontic treatment and had a positive attitude toward it. Females had very good knowledge, satisfaction and positive attitude compared to the males regarding dental esthetics and treatment. House surgeons were much more aware, very much satisfied and had a more positive attitude than 1 st year students.
\end{abstract}

Keywords: Dental Malocclusion; Self-Concept; Dental Students

\section{Introduction}

Measuring and recording the prevalence of mal-occlusion and treatment need in a population was useful for the planning of orthodontic services. Without a satisfactory estimate of the need and demand for treatment, it was difficult to develop and organize meaningful orthodontic services(Tulloch JF\& Jones $M$ 1984).Orthodontic treatment was often carried out to improve the patient's dental appearance. The main factors influencing the decision for treatment were esthetic improvement and psychological aspect. In addition, knowledge about the attitude of patients to malocclusion was becoming increasingly important in orthodontics (Helm S \& Solow B 1985), (Espeland LV\& Stenvik A1991).

The orthodontist routinely evaluates his patients and prescribes treatment plans in order to satisfy the often stated goals of good dental function, stability of teeth and jaw position, and dental esthetics. While the first two considerations have been researched and are continually discussed in all the specialties of dentistry, the last aspect dental esthetics has escaped research attention (Tang EL\& So LL1995). The lack of research material in this area is not due to a lack of interest in the subject but to the difficulty of measuring exactly what "Dental esthetics" actually means. Esthetics is judgmental commodity, and the assumed variability in individual judgments (beauty is in the eye of the beholder) makes it difficult to make generalized statements (Cochrane SM \&Hunt NP 1997), (McGorray SP\& Yurkiewicz L 1999).

The aim of this study was to assess the self-evaluation and satisfaction of dental appearance among dental students. The objectives of this study were to assess the knowledge and attitude toward orthodontic treatment and comparing between different class groups and sexes.

\section{Material \& method}

The study participants were 300 dental students of Peoples dental academy Bhopal, Madhya Pradesh. The study group comprised 100 males and 200 females of I, II, III, IV B.D.S. Students and House surgeons, aged between 18 and 26 years [Table 1].

Table 1: Distribution of Students According to Year and Sex

\begin{tabular}{llll}
\hline STUDENTS & SEX & & TOTAL \\
& MALE & FEMALE & \\
\hline 1ST YEARS & 27 & 24 & $\mathbf{5 1}$ \\
2ND YEARS & 14 & 38 & $\mathbf{5 2}$ \\
3RD YEARS & 12 & 43 & $\mathbf{5 5}$ \\
4TH YEARS & 18 & 46 & $\mathbf{6 4}$ \\
INTERN & 29 & 49 & $\mathbf{7 8}$ \\
TOTAL & $\mathbf{1 0 0}$ & $\mathbf{2 0 0}$ & $\mathbf{3 0 0}$ \\
\hline
\end{tabular}

The data for this study were collected visiting to the class-rooms of subjects and were requested to complete a structured questionnaire. The questions were prepared as follows: Seven questions on awareness about their dentition, four questions on their self-satisfaction and six questions about their attitude toward orthodontic treatment. Each question had three possible answers, ranging from the positive response to a negative response, and these answers were given scores ranging 0-2, the highest score to the best and the lowest to the worst. The test items assessed the subject's ability to recognize the presence or absence of malocclusion, knowledge to perceive the impact of mal-occlusion and attitude about orthodontic treatment.

Statistical analysis of the data set were performed by grouping the answers to each of the questions into three categories: A negative response, an average response, and a positive or favorable 
response. Categorical variables were evaluated with a Chi-square test. Statistical significance was set at $\mathrm{P}<0.05$.

\section{Results}

Seventy 0 percent of the students were aware of their dental esthetics, $20 \%$ were not aware and $10 \%$ did not have knowledge about esthetics at all [Table 2]. About $98 \%$ of females had very good knowledge about dental esthetics compared to $95 \%$ of males. However, the differences are statistically not significant.

Table 2: Awareness about Their Dental Esthetics

\begin{tabular}{ll}
\hline Questions & \multicolumn{1}{l}{ Subjects (N=300) In Percentage } \\
& YesNo Do Not Know \\
\hline $\begin{array}{l}\text { Do you think healthy and } \\
\text { well arranged }\end{array}$ & 9532 \\
$\begin{array}{l}\text { Teeth are important for } \\
\text { your appearance? }\end{array}$ & \\
$\begin{array}{l}\text { Are you satisfied with } \\
\text { your dental esthetics? }\end{array}$ & 65305 \\
$\begin{array}{l}\text { How do you feel about the } \\
\text { appearance of your teeth? }\end{array}$ & 702010 \\
$\begin{array}{l}\text { Do you have any trouble } \\
\text { while speaking, chewing, } \\
\text { facial muscle pain caused } \\
\text { by teeth arrangement? }\end{array}$ & 8902 \\
$\begin{array}{l}\text { Do you think you should } \\
\text { have orthodontics } \\
\text { treatment? }\end{array}$ & 30628 \\
$\begin{array}{l}\text { Would you agree readily } \\
\text { orthodontic treatment if a } \\
\text { dentist or parent suggested } \\
\text { it? }\end{array}$ & 652015 \\
$\begin{array}{l}\text { Do you think your smile } \\
\text { could be better if teeth } \\
\text { were better aligned? }\end{array}$ & 501636 \\
\hline
\end{tabular}

Self-satisfaction with the attractiveness of their teeth indicated a fairly objective evaluation of their own dental malocclusion situation. About $10 \%$ of the subjects were satisfied with the attractiveness of their teeth, $90 \%$ of the subjects reported negative feeling toward their teeth [Table 3].

Table 3: Self-Satisfaction about Their Dental Esthetics

\begin{tabular}{ll}
\hline Questions & $\begin{array}{l}\text { Students (N=300) In } \\
\text { Percentage } \\
\text { Not At All All The } \\
\text { Time }\end{array}$ \\
\hline $\begin{array}{l}\text { Have you found that other people have } \\
\text { commented on the appearance of your teeth? }\end{array}$ & 2575 \\
$\begin{array}{l}\text { Have you found that other people have teased on } \\
\text { the appearance of your teeth? }\end{array}$ & 1090 \\
$\begin{array}{l}\text { Do you try to avoid smiling because of the } \\
\text { appearance of your teeth? }\end{array}$ & 595 \\
$\begin{array}{l}\text { Do you ever cover your mouth because of the } \\
\text { appearance of your teeth? }\end{array}$ & 595 \\
\hline
\end{tabular}

40 percent of subjects were very much satisfied with the attractiveness of their teeth, and $24 \%$ of these were not satisfied. This is highly statistically significant $(\mathrm{P}<0.05)$ [Table 4$]$.

Table 4: Attitude toward Orthodontic Treatment

\begin{tabular}{ll}
\multicolumn{1}{c}{ Table 4: Attitude toward Orthodontic Treatment } \\
\hline Questions & $\begin{array}{l}\text { Subjects }(\mathrm{N}=300) \text { In } \\
\text { Percentage } \\
\text { Negative No Feeling } \\
\text { Positive }\end{array}$ \\
\hline $\begin{array}{l}\text { What kind of teeth do you have? } \\
\text { Are your teeth well aligned? }\end{array}$ & 121078 \\
$\begin{array}{l}\text { How satisfied are you with your teeth? } \\
\text { How much do you like the way your teeth }\end{array}$ & 243640 \\
look? & 201268 \\
$\begin{array}{l}\text { How much do your teeth affect the way your } \\
\text { face looks? }\end{array}$ & 72820 \\
$\begin{array}{l}\text { Do you think your smile could be better if } \\
\text { teeth were better aligned? }\end{array}$ & 581230 \\
\hline
\end{tabular}

Seventy-six percent of the females were satisfied with the attractiveness of their teeth and only 70 percent of males. But there was no statistical significance found. About $40 \%$ of the subjects were satisfied with the attractiveness of their teeth, $36 \%$ of the subjects reported negative feeling toward their teeth, $18 \%$ of the subjects showed a strong positive feeling toward their dentition.

Regarding the attitude toward orthodontic treatment, 30\% had strong positive attitude, $58 \%$ were satisfied with their attractiveness and $12 \%$ were not aware of it [Table 4].

Satisfaction versus attitude

When asked about how many students were un-satisfied about their dental attractiveness and had a positive attitude toward orthodontic treatment-78\% of subjects were un-satisfied of which $56 \%$ had a positive attitude toward orthodontic treatment. This is highly statistically significant $(\mathrm{P}<0.01)$.

When compared among different class groups about the knowledge of dental esthetics, House surgeons were very much aware of it followed by final year students. Moreover, there was no statistical significance found among the various classes. $1^{\text {st }}$ year students were not aware of dental esthetics very much.

When asked among different class groups about satisfaction of dental esthetics, House surgeons were very much satisfied about their teeth followed by final years. All the class groups were happy with their attractiveness almost equally. However, the House surgeons and $2^{\text {nd }}$ years were not happy with their dental esthetics. This was not statistically significant.

When the attitude toward orthodontic treatment was compared among different classes, House surgeons had more positive attitude with the least among the $1^{\text {st }}$ year students. Among satisfaction of dental attractiveness, $1^{\text {st }}$ year students and House surgeons were very much satisfied. $3^{\text {rd }}$ year students were least satisfied. No statistical significance was found.

Among Females there was almost even split between strongly positive $(50 \%)$ and satisfactory $(50 \%)$ attitude toward orthodontic treatment, there was no statistical significance found between males and females. The most influencing variable was found that, the teeth affect the way their face looks, and this was considered to be the most influencing factor among all the classes.

\section{Discussion}

The importance of patients' perceptions regarding orthodontic treatment cannot be underestimated as it is the patients who receive treatment and need to gain satisfaction from improved esthetics and function. (Birkel and K\& Wisth PJ 2000).

It had been hypothesized that increased experience with and availability of orthodontic service should be translated into differences in esthetics rating and perception of treatment need (Mandall NA \&McCord JF2000). Similar results have been obtained in our present study where $75 \%$ of the dental students who were having knowledge about orthodontic treatment were aware of dental esthetics.

The decision making process that a person undertakes when judging his/her own dental esthetic satisfaction may be broken down into several steps. First, knowing about the awareness and their own dentition, second their self-satisfaction, and finally their attitude toward orthodontic treatment. We may postulate that females had very good knowledge about dental esthetics compared to the males.

Regarding self-satisfaction about their teeth, the study indicates that the subjects did make fairly accurate self-evaluation of their own malocclusions (Crooked Teeth). The unsatisfied subjects with their dental esthetics had a positive attitude toward orthodontic treatment. The satisfied subjects with their dental esthetics were aware of the attractiveness of their teeth. This is also highly statistically significant.

The sixth difference is probably due to the fact that the standards for acceptable facial form are more clearly delineated for females. Thus, deviations are in dental form that adversely influence facial 
outline are more important to females than males. Similar results were obtained by Goel (Shue-Te Yeh M, \&Vlaskalic V2000). The subjects who had malocclusion and did not report to the orthodontic clinic seems to believe that, teeth did not affect their esthetic value and this appeared to be more of an ignorance that teeth does significantly affect facial appearance, and lack of knowledge was the main factor that kept away from treatment.

Kerosuo et al. study concluded that access to free of cost orthodontic treatment was likely to affect the treatment rate. Whereas, it did not seem to influence the self-perceived need for treatment (Bentele MJ\& Beck FM 2002).

Similar study conducted by Helm et al. suggested that certain malocclusions especially conspicuous occlusally and space anomalies may adversely affect body image and self-concept not only at adolescence but also in adulthood (Goel S 2002).It is in the strongest association with study conducted by Birkel and et al. That both children and parents rate pleasant esthetics as an important factor for psycho-social well-being (Hunt O 2002).

In accordance to Bentele et al., Index of Orthodontic Treatment Need is a promising teaching aid for improving educational outcomes for orthodontic referral when sufficiently prepared to dental students to diagnose malocclusion and make appropriate referrals of potential orthodontic patients. (Kerosuo H \& Kerosuo E 2002).

The limitation of this study, is that the dental students may not represent the general population of the society. Further crosssectional studies are required to include more numbers of participants of different age groups.

\section{Conclusion}

A questionnaire study evaluated the awareness about teeth, level of self-satisfaction, attitude toward orthodontic treatment and the overall perception of dental appearance among a group of dental students.

From the study done it was found that the subjects had:

- Good knowledge about the orthodontic treatment and positive attitude toward orthodontic treatment.

- The teeth affect the way their face looks, dental attractiveness the most influencing variable to perceive orthodontic treatment.

- Females had very good knowledge, satisfaction and positive attitude compared to the males regarding dental esthetics and treatment.

- House surgeons were much more aware, very much satisfied and had a more positive attitude than $1^{\text {st }}$ year students.

\section{Acknowledgement}

We sincerely thanks to my parents, friends and my faculty, Department Of Orthodontics who supported during the study.

\section{Conflict of inerest}

No conflict of interest involved so ever.

\section{Source of finding}

Nil.

\section{References}

[1] Tulloch JF\& Jones M 1984), A comparison of attitudes toward orthodontic treatment in British and American communities. Am J Orthod.85,25-9. https://doi.org/10.1016/0002-9416(84)90064-2.
[2] Helm S \& Solow B 1985), Psychosocial implications of malocclusion: A 15-year follow-up study in 30-year-old Danes. Am J Orthod.87,110-8. https://doi.org/10.1016/0002-9416(85)90020-X.

[3] Espeland LV\& Stenvik A1991), Perception of personal dental appearance in young adults: Relationship between occlusion, awareness, and satisfaction. Am J Orthod Dentofacial Orthop.100, 234-41. https://doi.org/10.1016/0889-5406(91)70060-A.

[4] Tang EL\& So LL1995), Correlation of orthodontic treatment demand with treatment need assessed using two indices. Angle Orthod .65, 443-50.

[5] Cochrane SM \&Hunt NP 1997), Perceptions of facial appearance by orthodontists and the general public. J Clin Orthod .31, 164-8.

[6] McGorray SP\& Yurkiewicz L 1999), Taylor MG, King GJ. Evaluation of orthodontists' perception of treatment need and the peer assessment rating (PAR) index. Angle Orthod.69,325-33.

[7] Birkeland K\& Wisth PJ 2000), Relationship between occlusion and satisfaction with dental appearance in orthodontically treated and untreated groups. A longitudinal study. Eur J Orthod.22,509-18. https://doi.org/10.1093/ejo/22.5.509.

[8] Mandall NA\&McCord JF2000), Worthington HV, O'Brien KD. Perceived aesthetic impact of malocclusion and oral selfperceptions in 14-15-year-old Asian and Caucasian children in greater Manchester. Eur J Orthod.22,175-83. https://doi.org/10.1093/ejo/22.2.175.

[9] Shue-Te Yeh M, \&Vlaskalic V2000), Boyd R, Richmond S. The relationship of 2 professional occlusal indexes with patients' perceptions of aesthetics, function, speech, and orthodontic treatment need. Am J Orthod Dentofacial Orthop .118, 421-8. https://doi.org/10.1067/mod.2000.107008.

[10] Bentele MJ\& Beck FM 2002), Efficacy of training dental students in the index of orthodontic treatment need. Am J Orthod Dentofacial Orthop.122,456-62. https://doi.org/10.1067/mod.2002.126895.

[11] Goel S 2002), Orthodontic treatment need-an orthodontist's and patient's perception. J Indian Orthod Soc.35,28-35.

[12] Hunt O 2002), the aesthetic component of the index of orthodontic treatment need validated against lay opinion. Eur J Orthod.24,53-9. https://doi.org/10.1093/ejo/24.1.53.

[13] Kerosuo H \&Kerosuo E 2002), Subjective need and orthodontic treatment experience in a Middle East country providing free orthodontic services: A questionnaire survey. Angle Orthod.72,56570 . 